переходом студентів на старші курси, все більше має набувати, за словами О.Г. Мороза, характеру дослідницького пошуку. 3 матеріалом, який виноситься на самостійне вивчення, для більшого поглиблення проблемних тем лекцій сучасний студент більш мотивований виконувати творчі науково-дослідні завдання: підготовка доповідей, рефератів, дослідження шкільного досвіду, виступ на студентських наукових конференціях, підготовка до колоквіумів, написання курсових, дипломних робіт. Така їхня практична діяльність буде більш педагогічно ефективною для формування професійної компетентності майбутнього фахівця. Також важливими в організації самостійної роботи студентів науковець вважає проведення консультацій, які можуть бути як основною формою навчального процесу, так $i$ додатковою. Призначення консультації- надання допомоги в самостійній роботі студентів та навчати їх учитись. Окрім того, самостійна навчальна робота студентів має бути організованою, за умови формування у них об'єктивної самооцінки в єдності з виробленням навичок самостійної пізнавальної діяльності. Вона має слугувати активним засобом для осмислення студентом навчальної інформації, застосування одержаних знань, умінь на практиці. О. Мороз наголосив також на важливому значенні системного та постійного характеру самостійної навчальної роботи студентів, що може бути забезпечено не на збільшенні часу, а на більш раціональному розподілі його між предметами відповідно до семестрового графіка з урахуванням значення їхньої специфіки.

Ключові слова: самостійна робота, навчальна позааудиторна робота, ефективні педагогічні умови, практична підготовка студентів.

UDC 371

N. Postoiuk, Ph. D. (Pedagogical of Sci.)

Taras Shevchenko National University of Kyiv, Kyiv, Ukraine

\title{
PECULIARITIES OF PRACTICAL TRAINING OF BIOLOGY TEACHERS IN D. SERGIENKO'S PEDAGOGICAL HERITAGE
}

D. Sergienko's ideas concerning the practical training of biology teachers have been analyzed. The main objectives and requirements to the teacher of biology at school have been highlighted. The peculiarities of organization of observation, experiment, laboratory and practical works have been revealed. The conditions of formation of students' abilities and skills of research character, as well as factors, which promote the development of interest in research work, have been determined. This scientific research has revealed that $D$. Sergienko considered the practical training of biology teachers as a very important thing because effective teaching of biology could help to improve the state of agriculture in the country, also this educational subject cultivates love for nature, expands knowledge about plant and animal life, promotes the choice of profession in the agro-industrial sector. D. Sergienko was sure that the biology teachers have a huge responsibility, because they have to raise the awareness of children in creative work in rural society. This goal can be realized if you have such personal qualities as the teacher's love for this subject, pedagogical skills, the ability to supervise and teach the children, the ability to work with the public and, especially, with children's parents.

Keywords: practical training, D. Sergienko, observation, research, biology teacher.

Formulation of the problem. The problem of practical training of teachers is very actual today, because it is one of the most important stages in the formation of a professional. If a student is prepared for future activities qualitatively, then he will be able to apply the obtained theoretical knowledge in practice, will receive the necessary knowledge and skills, will be competitive at the modern labor market. The reform of education in Ukraine is aimed at improving the practical training of students, the formation of general, integral and subject competencies. Program learning outcomes include knowledge and understanding of the subject area and professional activity, the ability to apply knowledge in practical situations and teamwork, ability to identify, solve problems. In accordance with the new requirements teachers must describe the expected learning outcomes in detail, forms, methods and teaching techniques, as well as assessment methods for the writing new programs for disciplines. In this case, the experience of domestic educators, who offered different ways to improve the training of future teachers may be useful. In particular, D. Sergienko's methodological recommendations concerning the organization of the work of biology teachers in secondary schools are worth attention.

Analysis of recent research and publications. The practical training of biology teachers has become the topic of research for many Ukrainian scientists. Problems of methodical preparation of teachers of natural sciences disciplines were studied by T. Gusakovsky, Yu. Shapran, L. Nikitchenko, N. Levchuk, I. Moroz and others. The questions of the peculiarities of the methodology of teaching biology were studied by M. Versilin, V. Kuznetsov, M. Matveev, V. Kolodiy, V. Sobol, D. Stepanyuk, O. Honchar, L. Rybalko, I. Sudakova and others. In particular, L. Nikitchenko, N. Levchuk are sure that "teachers of natural sciences must be able to establish the relationship between theory and practice when studying the course of biology at school, scientifically competently and didactically feasible to organize educational work about subjects of the natural cycle at the educational-research land site, during excursions, in out-of-school establishments. The students' knowledge obtained during professional practice contributes to the rational conduct of teaching and research work at the lessons, mastering the methods of its implementation, organizing naturalistic and environmental work in the school" [1, p. 4].

Research goal and objectives. The goal of the article is to analyze D. Sergienko's ideas concerning the practical training of biology teachers. To achieve the goal, the following objectives were set: 1) to highlight the main tasks of biology teachers in school and the requirements to them; 2) to reveal the peculiarities of the organization of observations, researches, laboratory and practical work; 4) to determine the conditions for the formation of students' abilities and skills of research character, as well as factors that contribute to the development of interest in research work.

Study presentation. D. Sergienko supposed that during the preparation of biology teachers the methodology of teaching should be based on the didactic principle with combining theory with practice in the process of work with the program. He offered through the improvement of biology teaching successfully to accomplish the following objectives: to develop cognitive interest in the surrounding world, to develop the ability to apply theoretical knowledge in practice, to form children's love for nature and creative approach to work. The scientist emphasized that it is very important to construct all educational work at the lessons so that children perceive plants and animals as living beings in their unity with the conditions of existence. He believed that "only the feeling of alive being and knowledge of the physiological needs of this organism can provide an attempt to create the best conditions for their development, a careful attitude to plants and animals, which causes a desire to learn more deeply about their physiological needs, the means to satisfy these needs, and the pupils start to listen to an explanation 
of the teacher with a great interest, to learn actively the material of the textbook, to look for an advice in the literature" [2, p. 34]. D. Sergienko remarked that all children love nature, especially younger, and the purpose of the teacher is to develop this feeling, to make it conscious and directed. It is possible to achieve this if teachers spend time with children in nature, studying its phenomena in the process of laboratory and practical work. Starting from the first class, it is necessary to carry out systematic work about children looking after plants and small animals in the corner of wildlife, in the school educational-research land site and in the nature; room flowers in classes should be not only an ornament, but also educational-upbringing factor; it is necessary that each pupil at home has plants and animals, that he or she looks after.

D. Sergienko believed that conducting observations and practical care of plants and animals from the younger age would prepare children for a deeper understanding of the idea of unity of the organism with the conditions of existence, and the quality of preparation for practical activity depends on the teacher's ability to bring to the consciousness of the students the correct understanding of this unity [2, p. 35]. The scientist considered the teaching of biology is connected a lot with the improvement of the state of agriculture. $\mathrm{He}$ expressed the opinion that well-organized research and practical work at the village school on biology contributes to the training of young people in agriculture, and the school interest in creative work in the agro-industrial complex turns into a vital interest that determines further activity.

$D$. Sergienko described the main objectives of the village school and the biology teacher in establishing and strengthening the connection with agricultural production. First of all, the biology teacher, taking into account the program purposes of classroom work and local conditions, develops an annual plan of educational work of the school. The plan includes the contents, methods of socially useful work of the children's collective, the time, who performs it (class, group, class teacher). The plan must be discussed with pupils, teachers, at a meeting of the pedagogical council, and then this plan, as an integral part of the year plan, is approved by the director of the school. D. Sergienko recommended that the content of the planned objectives should correspond to the age characteristics of children and their knowledge in each individual case. The scientist stated that the organization of children's groups for one or another socially useful work was based on the same pedagogical principles as conducting practical laboratory classes in the classroom and at the school educational-research land site, namely: a clear and understandable goal for children; clearly defined ways and methods and time of the work; definition of individual and group tasks; help for children and control during work; widespread use of appropriate incentive measures; wide deployment of the competition. He believed that a conscious labor discipline in the children's collective will be provided only under these conditions [2, p. 160-161].

D. Sergienko noted that the subject and content of children's work in agricultural production should be directed to:

1 ) studying of the best local varieties of fruit trees and berry bushes, their reproduction, distribution and improvement;

2 ) the cultivation of new crops for the area;

3) work on variety testing;

4) studying local useful small plants, in particular fodder grasses;

5) the spread of silkworm, rabbit meat, highly productive breeds of poultry:

6) patronage of young farm animals;

7) participation in the creation of a forage base for fish farming, development of fisheries and fish farming;
8) the fight against harmful insects and rodents in gardens, towns and streets;

9) connection with the house of agro-culture and agrolaboratories;

10) assistance to farms during the summer holidays about caring of plants and animals and in harvesting [2, p. 161-162].

The scientist expressed the opinion that one of the most grateful topics of practical social work of children in the agriculture is the cultivation of new plants on school's educational-research land site. This topic is interesting and is a broad field for research work, opens up the opportunity to contribute to the further development of the domestic economy, and the destruction of harmful insects and rodents is an important form of children's participation in the struggle for high yields. The educator stressed on the specification of programs and textbooks on biology, which can be achieved through the proper organization of the educational process at school, extracurricular work concerning agriculture and, above all, the skillful creative work of a biology teacher. The scholar expressed the opinion that the development of abilities, inclination in children is a great and honorable thing, and prospects for further creative growth is very important for the development of each child [2, p. 167].

$D$. Sergienko said that a huge role and responsibility in the upbringing and teaching pupils belongs to the biology teacher. He noted: "The success of all educational work depends on the teachers' knowledge, their qualifications, their love to work, their authority and communication with the public and, especially, with the pupils' parents. The strong relationship between the teacher and the children, as well as the study of the interests and demands of pupils, the creation of appropriate conditions for the development of these interests and inquiries - all this is the key to success in the practical training of students to the future activities" [2, p. 168].

$D$. Sergienko put forward the following requirements to the biology teacher:

1) the goal of biology teachers is to stimulate, educate and strengthen the interests of children in creative work in rural production. The more stimulating conditions for the development of a certain interest, the faster a pupil will develop, so this interest will be longer and more permanent. Such conditions should be created, first of all, by the biology teacher in the process of teaching. The teachers' love and interest to his subject, his pedagogical skills - this is what largely ensures the children's interests [2, p. 27];

2 ) it is necessary to establish a causal relationship between changes in conditions and changes in the organism in the process of observation and preliminary work for correct children understanding the problems of the development of wildlife. To do this, the teacher must be able to do it and teach the children how to observe. The ability to observe is the basis of all research work, and therefore the teacher must develop children's observation in all ways [2, p. 40-41];

3 ) responsibility for the organization of research work is assigned to the biology teachers, whom D. Sergienko advised to raise their knowledge systematically, to study the experience of the best teachers and researchers carefully, to follow the achievements of biological science and practice of agriculture [3, p. 74];

4) the biology teachers should unite around them the other teachers, systematically instruct them and children about the questions of methodology and techniques of research work, to help in the work, to check how their instructions are implemented in practice. It is advisable to hear reports periodically from the biology teachers, as well as classroom teachers about the status and prospects of the research work at the pedagogical council [2, p. 77]; 
5) the biology teacher not only conducts a scientifically substantiated classes, but also additionally reads the review lectures (for example, on topics: diversity and adaptability of organisms, the development of cells from living non-cellular substances) [2, p. 22].

Nowadays D. Sergienko's ideas about practical methods of teaching biology are very actual, namely an observation, a research, laboratory and practical work. In his opinion, these methods help to develop the correct ideas and concepts for learning changes in the natural phenomena of nature. He stated that an active person is formed due to observation, serious and creative attitude to the work, and the key to the creative growth of pupils is an understanding of the children and their capabilities [3, p. 8-9].

The teacher believed that the ability to observe can be developed in the process of creative and systematic work, life experience, and it needs to be developed from childhood. According to D. Sergienko, the ability to observe the life of nature should be a professional feature of biologists and agronomists. Pupils should be taught to observations with the help of instruments that are being constantly improved in schools, starting from dandruff, microscope and ending with automatic devices for recording meteorological observations and others that meet the current level of science and technology. According to the teacher, the observer should always be objective, to take into account and direct the course of development of certain phenomena, to establish objective laws [3, p. 9].

D. Sergienko proposed a number of rules on the basis of which the teacher should develop observation in children:

1 ) statement of a clear and intentional purpose of observation;

2) a written plan of observation developed by the teacher, which will help to teach pupils to notice all the essential things that are connected with the task;

3 ) compulsory preparation of pupils for observation, giving the necessary knowledge about the object ensures the success and the value of observation;

4) systematic observation;

5 ) the connection of perception with the active process of thinking, which is manifested, for example, in the comparison of objects and phenomena, in establishing a causal relationship between them, in the ability to draw conclusions from the theory and practice;

6 ) keeping systematic entries in the diary and substantiating the results of the work (the teacher helps the pupil to present the changes, impressions and conclusions as markedly as possible, as well as to organize the reporting on the work done in the form of a report at the meeting, making the herbarium, collections, diagrams, charts etc.) [2, p. 38].

$D$. Sergienko devided observations into short-term, during one or several lessons (for example: observations of tracking of silkworm caterpillars, curling of cocoons), and long-term (for example: the full cycle of plant development, meteorological observations and others). According to D. Sergienko, the observation of certain facts and phenomena leads to conclusions and generalizations, and this new knowledge is used in practical work. The scholar paid a lot of attention to such methods as laboratory and practical work in the course of natural science and biology [2, p. 43].

The scientist was convinced that during the laboratory and practical work pupils consolidate, expand and deepen theoretical knowledge, acquire practical skills and abilities. Laboratory work enhances interest, develops the initiative of children, independence and perseverance in work, teaches clarity, discipline and attentive attitude to work.

D. Sergienko determined that laboratory and practical work can be confirmatory and exploratory. An example of the first can be the story of the cellular structure of the plant, when the teacher shows the corresponding table, and only after the pupils have mastered the material, organizes the laboratory work with a microscope, under which the pupils initially examine the ready preparations, and then they make cuts themselves and study them. Experimental practical work requires the formulation of a task for pupils or members of a circle of young naturalists, which they solve independently through laboratory experiments. The themes of such works can be the study of the influence of temperature on the development of plants, the impact of fertilizers on the yield of agricultural plants etc. [2, p. 43].

D. Sergienko remarked that it is extremely important "to teach children to record the course of laboratory work, observations, conclusions. Such skills are not achieved immediately, therefore, at the beginning it is possible to do the writing proposed by the teacher in the workbooks, and after several such attempts, the pupils will independently deal with it in the process of laboratory work. It is desirable to illustrate entries with the help of drawings from nature not from the textbook" [2, p. 43].

The educator stated: "In the process of preparing and conducting researches during laboratory studies, on a research land site, in agriculture, pupils acquire practical skills and abilities, they develop a labor initiative, they receive physical and moral training for work" [3, p. 48].

$D$. Sergienko highlighted a number of conditions for the formation of pupils' research skills and abilities. They are interpreted as follows:

1) the psychological training of each pupil to successfully mastering skills and abilities, assuring that everybody can do the work well;

2) teaching pupils to follow the methods of work of the teacher, analyze them, bringing up the need to observe, feel and perceive certain stages of mental and practical work;

3 ) careful monitoring of the first methods of pupils work during the implementation of practical and research tasks. The first actions of the pupils are always timid, cumbersome, therefore it is necessary to not only explain one or another action, the reception of work, but also virtually prove them why so, and not otherwise, to see that they recreate, realize and master each reception;

4) disclosure of the value of research work in the general labor system;

5) systematic practical and research work in the classroom, in the corner of wildlife, in the office, in the greenhouse, on the experimental land site, ranging from simple works to complex experiments;

6) mastering skills and abilities to enhance the pupils' autonomy in carrying out practical and research tasks with the obligatory control of the teacher;

7) understanding by pupils the purpose of work from the words of the teacher or in a written instruction, drawing; reproduction in the memory of theoretical knowledge for the implementation of a particular work;

8) forming pupils' conscious and active attitude to work, interest in their practical and research work;

9) self-critical analysis of the successes and disadvantages in research work;

10) socially useful orientation of pupils' work: cultivation of high yields, increasing the productivity of animals, working out of the most effective methods of research work, designing of devices, etc.;

11) creation of the necessary conditions for research work: well-equipped biological cabinet, experimental land site, greenhouse, meteorological station, prepared tools and instruments, available scientific popular literature concerning science, biology, foundations of agriculture; 
12) the creative scientific work of a teacher, who must follow the development of science, the experience of research in agriculture and in schools, master the methodology and techniques of conducting a school researches [3, p. 42-50].

According to $D$. Sergienko pupils learn the following things in the process of formation of research skills:

1) to manage the growth and development of plants according to a previously made plan, to apply knowledge in practice in order to operate manual and machine tools;

2) to conduct researches on school educational-research land site, which will help to work and conduct researches in production conditions;

3) to plan the research and to draw up the schemes for carrying out certain processes (soil cultivation, study of the plant nutrition system, application of certain agro measures), to observe, to work out the consequences of research work;

4) apply a system of agro-biological measures aimed at cultivating a high yield of plants or increasing the productivity of animals, or studying this or that agro-technical measure and its impact on the quality and quantity of the crop, animal productivity [3, p. 48].

D. Sergienko believed that each "research" is a difficult complex of work with agricultural plants and animals, which requires the consistent application of an entire system of exercises, actions, operations. So, in order to grow a high yield of grain crops, including wheat, it is necessary to study the soil on which wheat is sown, the system of fertilizing, the presence of the necessary nutrients in the soil, to determine what substances are missing in it, how many and what fertilizers to add to this culture, ways of introducing them under plowing, cultivation in the process of vegetative development by means of nutrition, work on snow draining, fighting with ice covering, spring harrowing etc." [3, p.48-49].

The analysis of $D$. Sergienko's works allows to state that although the scientist pointed to many common features of researches and observations, he did not identify them, and said that the experiment is a research in the narrow sense. He considered observation as the necessary stage of the research and noted: "Observation is the fixation of facts as given by nature, regardless of the desire of the researcher," but in the experiment the same researcher does not only passively observes the nature phenomena, but interferes with them creatively and actively, selects and allocates some of them, artificially reproduces in specially created conditions (if studying them in the natural environment is connected with difficulties), that is, the researcher according to his plan can recreate the phenomena under study in different conditions and involve in the experiment new factors" [3, p. 9-10].

D. Sergienko supposed that it is very important for conducting researches and observations to teach pupils correctly and logically express their thoughts, use scientific terms and positions for determining the quality of the conducted research, during the experiment to turn more often the pupils' attention to certain phenomena, persistently seek clear concepts of objects and phenomena through repetitions in different versions (explanation, demonstration of visual aids, pupils' performance of an independent task) [3, c. 7]. The educator believed that, fulfilling the tasks of the research character, the pupils are acquainted with scientific facts, with the laws of biological and agronomic science, receive relevant knowledge about the life and development of plant and animal organisms, learn about the role of a person in improving and transforming nature. Researches help pupils to understand better the interconnection and interdependence in nature, the role of human labor and biological science in the development of agriculture industry. He was convinced that even the simplest researches about confirming the presence of chlorophyll in plants, plant respiration, growth etc., give students a lot of new knowledge, cause creative thinking, and researches of an experimental character positively influence the development of thinking: growing hybrid seeds, cultivating new forms of high-yielding plants or the improvement of the natural qualities of birds and other small farm animals [3, p. 7].

The scientist set the following requirements for the doing researches:

- clear planning;

- explaining of the purpose;

- pupils' mastering the foundations of science, which will help to understand better the laws of the development of plants and animals, and unpreparedness will force to act blindly, without using theoretical knowledge;

- the necessity of the control variant (the accuracy and reliability of the results of the research depends on the number of repetitions, especially on small areas, but in the practice the research work may not give a positive answer to the question, the researcher's intention may not be realized. This should not frighten, it is necessary to think, analyze, look for the reasons for the failure of the research, develop a new method) [3, p. 10-11].

D. Sergienko called for collective researches, believing that the division of tasks between the members of the team creates conditions for the development of the competition, therefore, the researches should be carried out by a class, a group, and elder pupils who have shown a certain interest in biology can conduct researches on their own. The teacher emphasized that the teacher and pupils must prepare for conducting the researches: they collect seeds, fertilizers, draw up a research plan, study literature etc. [3, p. 13].

The scientist described some of the factors contributing to the development of interest in research work:

a) various practical, laboratory works, experiments with plants and animals that give a relatively fast effect and results (work in greenhouses, in the corner of wildlife);

b) work with silkworms, chickens, rabbits etc.;

c) display and study of phenomena, objects in their movement and development;

d) interesting narrations, reports, disputes of pupils and reading short exciting passages of fiction or popular science literature, demonstration of visual devices, films, work with a microscope, making self-made visual aids;

e) availability of new elements in the work; acquaintance with the achievements of biological science, best practices, new objects for studying;

f) meeting with scientists, leaders in agriculture, brigades of pupils from neighboring schools;

g) participation in exhibitions of excellence, competitions for the best conducting of researches, observation, competitions, award winners, public review of the work of each pupil or a group in general [3, c. 14].

Conclusions. Scientific research showed that D. Sergienko had considered the practical training of biology teachers as a very important thing, because effective teaching of biology could help to improve the state of agriculture in the country. Biology brings up love for nature, expands knowledge about plant and animal life, promotes the choice of profession in the agro-industrial sector (growing new crops for the area, sorting, spreading silkworm, rabbit breeding, high-yielding and so on). D. Sergienko's ideas concerning the application of practical methods of teaching biology, namely an observation, a research, laboratory and practical work, have been revealed. The scientist put a huge responsibility to the biology teacher, whose goal is to bring up the children interest in creative work in rural society. This goal can be realized if the teacher has such personal qualities as love to the subject, pedagogical skills, the ability to supervise 
and teach the children, the ability to work with the public and especially, with the pupils' parents. D. Sergienko highlighted a number of conditions for the formation of pupils' abilities and skills of research character, as well as individual factors that contribute to the development of interest in research work.

References

1. Nikitchenko L. O., Levchuk N. V. Teoretyko-metodychni zasady pidhotovky maybutnikh uchyteliv pryrodnychykh dystsyplin u protsesi profesiynoyi praktyky: monohrafiya / L. O.Nikitchenko, N. V. Levchuk. Vinnytsya: TOV "Nilan-LTD", 2017. - $296 \mathrm{~s}$

2. Sergiyenko D. L. Pidhotovka uchniv z biolohiyi do praktychnoyi roboty $v$ sotsialistychnomu silskomu hospodarstvi / D. L. Sergiyenko. - K.: Radyanska shkola, 1950. - $172 \mathrm{~s}$.
3. Sergiyenko D. L. Formuvannya doslidnytskykh umin ta navykiv uchniv pry vyvchenni biolohiyi v V - VIII klasakh / D. L. Sergiyenko - K : Radyanska shkola, 1969. - $128 \mathrm{~s}$

Список використаних джерел

1. Нікітченко Л.О. Теоретико-методичні засади підготовки майбутніх учитепів природничих дисциплін у процесі фахової практики : монограффія / Л. О. Нікітченко, Н. В. Левчук. - Вінниця : ТОВ "Нілан-ЛТД", 2017. - 296 с.

2. Сергієнко Д. Л. Підготовка учнів з біології до практичної роботи в соціалістичному сільському господарстві / Д.Л. Сергієнко. - К. : Рад. школа, 1950. - 172 с.

3. Сергієнко Д. Л. Формування дослідницьких умінь і навиків учнів при вивченні біології в У-УІІІ класах / Д. Л. Сергієнко. - К. : Рад. школа, 1969. -128 c.

Надійшла до редколегії 09.03.19

Н. Постоюк, канд. пед. наук, асист.,

Київський національний університет імені Тараса Шевченка, Київ, Україна

\section{ОСОБЛИВОСТІ ПРАКТИЧНОЇ ПІДГОТОВКИ ВЧИТЕЛІВ БІОЛОГІЇ У ПЕДАГОГІЧНОМУ ДОРОБКУ Д. СЕРГІЄНКА}

Проаналізовано ідеї Д. Сергієнка стосовно практичної підготовки вчителів біології. Висвітлено основні завдання вчителя біології у школі та вимоги до нього. Розкрито особливості організації вчителем спостереження, досліду, лабораторних і практичних робіт. Визначено умови формування в учнів умінь і навичок дослідницького характеру, а також фактори, які сприяють розвитку інтересу до дослідницької роботи. Наукове дослідження показало, що Д. Сергієнко вважав практичну підготовку вчителів біології надзвичайно важливою, оскільки ефективне викладання біології може сприяти поліпшенню стану сільського господарства в країні, і цей навчальний предмет культивує любов до природи, розширює знання про рослинний і тваринний світ, сприяє вибору професії в агропромисловому секторі. Д. Сереієнко закликав до колективних дослідницьких робіт, вважаючи, що розподіл завдань між членами команди створює умови для розвитку конкуренції, тому дослідження мають виконуватися класом, групою, старшими учнями, які виявили певний інтерес до біології. Педагог наголошував, що здатність спостерігати може розвиватися в процесі творчої і систематичної роботи, життєвого досвіду, $і$ вона має розвиватися з дитинства. На думку Д. Сергієнка, здатність до спостереження за природою має бути професійною рисою біологів i агрономів. Учні повинні навчатися спостереженням за допомогою інструментів, які постійно вдосконалюються. Д. Сергієнко бує упевнений, що вчителі біології несуть величезну відповідальність, тому що вони повинні підвищувати обізнаність дітей у творчій діяльності в сільському суспільстві. Цю мету можна реалізувати, якщо є такі особисті якості, як любов вчителя до цього предмету, педагогічні навички, здатність контролювати і навчати дітей, вміння працювати з громадськістю $i$, особливо, з батьками дітей.

Ключові слова: практична підготовка, Д. Сергієнко, спостереження, дослід, вчитель біології.

Y. Spitsyn, Dr. of Sci. (Pedagogics), Prof. Taras Shevchenko National University of Kyiv, Kyiv, Ukraine

\section{THEORETICAL AND METHODOLOGICAL BASIS OF THE PRACTICAL AND PEDAGOGICAL EDUCATIONOF THE FUTURE AND CURRENT TEACHERS DEVELOPED BY A. D. BONDAR}

The article is devoted to the lecturers of pedagogical sciences, professor of the Pedagogy Chair of Taras Shevchenko National University of Kyiv. Work in the field of theoretical foundations, methodological bases for the preparation and conduct of various types of pedagogical practice of students. The relevance of the return to the origins of the development and methodology for the conduct of pedagogical practice of future pedagogical and scientific and pedagogical personnel with the aim of raising the level of education and adopting appropriate changes.

Keywords: pedagogical practice of students, content of practice, methods of preparation and conduct of practice.

Formulation of the problem. The Law of Ukraine "On Higher Education" stipulates that one of the main tasks of higher education is the formation of skills and practical skills of students (future young specialists) in the corresponding field of knowledge of a certain qualification. Undoubtedly, the most important condition for improving the quality of training of any specialist is the successful passing of professional practice, for the effective conduct of which clear organization is required. In accordance with the normative provisions of the Article 50 (part 1) of the Law of Ukraine "On Higher education" one of the forms of the organization of educational process is practical training. Provisions of the Article 51 of the Law of Ukraine "On Higher education" provides that the main normative requirements for the implementation of the practical training of the persons studying in higher educational institutions, are namely:

- practical training of the persons studying in higher educational institutions, is carried out by internship in enterprises, institutions and organizations according to the concluded higher educational institutions in the treaties or in its structural units that provide practical training.
- managers of enterprises, institutions and organizations must provide proper conditions for passing of the practice in production, observance of rules and norms of labor protection, technology safety and production sanitation in accordance with the law.

- internship of the student is carried out in accordance with the law [3].

"Regulations on the practice of students of higher educational institutions of Ukraine", approved by the order of the Ministry of Education of Ukraine of April 8, 1993. Provided that the aim of this practice is mastering modern methods, forms of organization and tools of the work in the industry of their future professions, forming them on the basis of the knowledge, obtained in the higher educational institution, professional skills and abilities to find independent solutions during a specific work in real market and production conditions, the need to systematically update your knowledge and creativity to apply them in practical activities [10].

The purpose of the publication is to analyze the current state, the problems of organizing the pedagogical practice of students taking into account the experience of A.D. Bondar, 